\title{
Developing an Interactive Non-formal Chemistry Setting and Investigating Its Effectiveness on High School Students' Attitudes towards Chemistry
}

\author{
Gökhan Demircioğlu ${ }^{1}$ \\ ${ }^{1}$ Fatih Faculty of Education, Karadeniz Technical University, Trabzon, Turkey \\ Correspondence: Gökhan Demircioğlu, Fatih Faculty of Education, Karadeniz Technical University, Trabzon, 61330, \\ Turkey.
}

Received: September 22, 2016

Accepted: October 8, $2016 \quad$ Online Published: October 19, 2016

doi:10.11114/jets.v4i12.1889

URL: http://dx.doi.org/10.11114/jets.v4i12.1889

\begin{abstract}
The main purpose of this study is to design an interactive non-formal chemistry environment and investigate its effectiveness on high school students' attitudes towards chemistry. Besides that, it is tried to determine to what extent students correlate these concepts with daily life. 14 voluntary students (5 female, 9 male) from different levels participated to conduct the experimental study. The chemistry laboratory of a high school is reorganized for this study. 7 chemistry activities which are intriguing and relevant to daily life were selected from different sources. At first, the students were informed about the study and then Chemistry Attitude Scale was applied as pre-test. The study was completed in total of 3 days. At the end of each day, the students filled a worksheet about the activities carried out during that day. After the completion of activities, Chemistry Attitude Scale and Experience Determination Survey were applied to the students. Furthermore semi-structured interviews were conducted with one student from each level. As a result of this study, the attitudes of the students increased positively and they regarding the working environment as 'entertaining, different, experience, collective, enjoyable and interesting'. Furthermore, the students' levels of correlating chemistry concepts with daily life were determined to be $67.5 \%$ on average.
\end{abstract}

Keywords: chemistry education, non-formal learning environment, worksheets

\section{Introduction}

\subsection{Introduce the Problem}

Learning can be stated as a life-long process that is independent from time and place. From this point of view, nowadays it can be said that individuals are in a continuous learning phase. Learning, from in-school to out-of-school learning, is classified as formal, non-formal and informal (Eshach, 2007). Formal learning occurs in an organized setting (in terms of objectives, time and resources) (Cedefop, 2008). This learning setting is designed according to the viewpoints of experts and may lead to formal recognition (diploma, certificate). İnformal learning occurs as a result of daily activities related to free time, family or work. This learning is not structured with the factors such as aim, time and instructional scaffolding. Ordinarily it is named as 'learning from experience' or simply 'experience'. Non-formal learning is often embedded in planned activities that are not designed as learning (Cedefop, 2008). Informal and non-formal learning are complementary of formal learning and they occur in many different ways and settings (zoo, science centers and museums, television, films, aquarium and arboretum, etc.) (Soh \& Mearah, 2013). Informal and non-formal science learning have an important role in helping all individuals, regardless of age in exploring science and technology. Learning in school (formal learning) is criticized because it was not sufficiently associated with real life experiences and real objects or events, and it is mostly based on the symbols and provides less opportunity for students to socialize themselves. On the other hand, it has been asserted that non-formal learning environments increased students' eagerness to learn, improved attitude and motivation for learning (Ramey-Gassert, 1997), which gives an opportunity to experience directly with real object, person and setting (Laçin-Şimşek, 2011). Such environments are designed according to interests and needs of individuals; individuals may come alone, in small or family groups of sexes, ages and subject expertise, with their previous learning experiences and wide range of learning styles in different ages and genders (Kola-Olusanya, 2005). Particularly, interactive ones help the physics, chemistry and biology lessons, which are typically regarded complicated subjects by the students, become more comprehensible. Informal learning 
environments can be evaluated as non-formal settings according to the way the visit is performed. If the visit is made in company with a teacher or a counselor intentionally, it can be expressed as non-formal learning activity.

The attitude is a phenomenon which may cause partiality in decision-making process and influences the individual's behaviors. Despite being discussed widely in literature, the attitude is a topic that must be studied, because it is an important determinant for learning. Reaching the desired success in education may be possible by means of recognizing the students' attitudes (Meyveci, 1997). The studies indicate that most of the students are having difficulty in understanding the abstract concepts in chemistry courses. And this may cause students to develop negative attitudes towards chemistry. In the literature, there is almost no study investigating the effects of informal and non-formal learning environments on the students' attitudes towards chemistry. Thus, in this study, it is aimed to design a non-formal learning environment for chemistry, to determine the effect of it on the students' attitudes, and to explore the association levels of students' everyday life events with the concepts under investigation.

\subsection{Literature Review}

Chemistry consists of many basic concepts which require cognitively abstract thinking (Zoller, 1990). Therefore, it is considered as a complicated discipline by the students (Kee \& McGovan, 1998; Reid, 2000; Koçak, 2011). It was also suggested that most of the students perceive chemistry as a course which they are obliged to pass (Koçak, 2011). However chemistry is a course that should be given in schools to prepare students for their career. Moreover, it is a fun discipline that helps the students understand the world they live in. Chemistry concepts that are theoretically taught in schools, explain the most of events or situations encountered in daily life (TPSI, 1991). Teaching theories adopted in Present Chemistry Teaching Program require the teachers to prepare learning environments that provide students a direct interaction with concrete materials (MEB, 2013). An important goal of chemistry instruction for students is to see the relevance of chemistry concepts to daily life. Unfortunately, in our schools the relationship between the theoretical concepts and daily life events is not sufficiently investigated. As a result of this, science courses are often felt to be irrelevant to daily life (Gilbert, 2006) and students develop negative attitude towards science courses. For instance, according to Gräber (1992) there are four reasons why students do not like chemistry course; bad image of chemistry, difficulty of the course, irrelevancy of chemistry course content with daily life and characteristics of chemistry teachers. Barke (1987) states inadequate numerical processing skills of students in chemistry course as a reason for their unwillingness about studying chemistry. On the other hand, Chemistry Curriculum also has an effect on the attitude towards chemistry course. If it could not meet students' expectations in the course, they might develop negative attitude towards chemistry (Bulte et al., 2006; Osborne \& Collins, 2001). In the our literature, many researchers also found that Turkish students have difficulty in correlating science concepts with daily life (Anagün, Ağır \& Kaynaş, 2010; Balkan Kıyıc1, 2008; Coştu, Ünal \& Ayas, 2007; Pınarbaşı, Doymuş, Canpolat \& Bayrakçeken, 1998; Taşdemir \& Demirbaş, 2010). Science centers and museums play a significant role on students' attitudes because they provide students an elusive set of opportunities for practical learning which are not possible in classrooms, regarding hearing, vision and sense of touch (Martin, 2003; Kelly, 2002). Researches indicate that using interactive activities in science teaching classes contributes to the correlation of science concepts with daily life events, in order to develop positive attitudes and scientific process skills and improve science literacy (Wellington, 1990; Bozdoğan, 2007). It is determined that students improve their scientific thinking skills in rich informal learning settings (Gerber et al., 2001). Meanwhile, it is argued that students can enhance their collaborative and independent learning skills with out-of-school scientific activities (Sturm \& Bogner, 2010). Daneshamooz et al. (2013) investigated the effect of science centers (museums) on students' attitudes. In one of the results of the survey conducted with 1002 students, it is found that students visiting science centers improve their attitudes towards science. When taking into account the gender, they determined that the attitudes of male students show a greater increase than female students. Ertaş-Kılıç \& Şen (2014), in their study investigated the effect of an instruction supported with out-of-school learning activities on students' critical thinking and attitudes towards physics. The study was conducted with 120 9th grade students. The results indicated that the instruction based on out-of-school learning activities improved students' critical thinking skills and attitudes towards physics. Armağan (2015), in his study, designed and applied an out-of-school learning environment model on the subject "the habitats of living", and evaluated its effectiveness. In the result of interviews he conducted with students, he determined that students attended the activities eagerly, made creative works in the activities, and found the activities very enjoyable. In addition, it was determined that students have begun to love science courses and their attention and curiosity towards science have increased. It is emphasized that informal learning environments whose main purpose is not learning may produce learning after the visit (Boisvert \& Slez, 1994). Additionally how long the visitors stay in the setting, whether they find the activities interesting or not, and to what extent they attend the activities are important in terms of the effectiveness of visit (Boisvert \& Slez, 1994). On the other hand, design of these kinds of activities is extremely important to get effective results. However there is no further information about how these settings should be and how they are prepared in the literature. The present study also considers to provide further evidence about how to design non-formal chemistry environments. 


\section{Method}

\subsection{Purpose of the Study}

Science centers, museums, zoos, aquariums and all of science portals are informal environments. Especially the experiences gained in the science centers help visitors to think like a scientist, build the foundation of scientific thinking and develop positive attitude towards science and technology. Thus, in this study a non-formal learning environment consisting of enjoyable and interactive chemistry activities is designed and its effect on high school students' attitudes towards chemistry is investigated. In accordance with this purpose, it is tried to find answers of the following questions below:

1. Is there any effect of interactive non-formal chemistry environments on students' attitudes towards chemistry?

2. Do students' attitudes towards chemistry differentiate according to class level and gender?

3. After the treatment, what are the students' levels of correlating the chemistry concepts under investigation with daily life? Are there statistically significant differences among their association levels according to class level and gender?

4. What are the students' opinions about interactive non-formal chemistry environment and activities?

\subsection{Research Design and Sample}

In this study, the mixed method which combines quantitative and qualitative methods was used. In the mixed method, data were collected by using quantitative and qualitative methods together (Creswell, 2013). The determinant for using this method is the research questions. In other words, while finding answers to the questions with one of the quantitative and qualitative methods, the mixed method is preferred. In this study both qualitative and quantitative research methods were used because the students' performances are necessary for measuring during and after the treatment. Also the present study consists of development, implementation and evaluation stages. Only quantitative or qualitative method cannot answer all research questions concerning these stages. Therefore, the mixed method is preferred in the present study. In the quantitative part of the study, the data acquired by attitude scale, the experience survey and worksheets are used. In the qualitative part the semi-structured interview data are collected.

The study group consists of a total of 14 students (four in grade 9, five in grade 10 and five in grade 11) of a high school in Akçaabat county of Trabzon province. 5 female and 9 male students attended the study. These students were chosen among the volunteers. Each student was given a code (for example 9B2; grade 9, boy, 2nd) to improve the readability of the work.

\subsection{Data Collection Tools}

In this study 'Chemistry Attitude Scale', 'worksheets', 'experience determination survey' and 'interviews' are used to collect the data.

1. Chemistry Attitude Scale: It is a scale which consists of 7 negative, 13 positive items, a total of 20 items, developed by Demircioğlu, Aslan and Yadigaroğlu (2013) in order to determine the students' attitudes towards chemistry. The scale consists of 2 sub-factors 'loving chemistry' and 'planning a career path devoted to chemistry'. Cronbach Alpha reliability is 0.89 for the whole scale, 0.90 for the first sub-factor and 0.81 for second sub-factor. The scale was applied to the sample twice before and after the treatment. The data was analyzed by using a non-parametric test because the number of sample was less than 30. The difference between the pre-test and post-test averages calculated from students' attitude scale compared with Wilcoxon Signed Rank Test, Mann Whitney U Test for the averages calculated according to gender variable, and Kruskall Wallis $\mathrm{H}$ Test for the averages calculated according to class level variable.

2. Worksheets: Worksheets can be used for different purposes such as eliminating misconceptions, learning new knowledge and recording data (Demircioğlu \& Atasoy, 2006). In this study they were used to determine in what level the students can transfer what they have learned from the activities to daily life. A worksheet was prepared for each activity. The worksheets contains gap-filling, structured grid, true false and open-ended questions. Worksheet for making glue experiment was given in Appendix as an example. A commission consisted of three experts in chemistry education and two experienced chemistry teachers determined the convenience and validity of worksheets. At the end of each day of visit, worksheets related to the activities carried out during the day were given to the students. Students filled each worksheet in about 15 minutes. In order to create a scoring standard in the worksheets, the maximum point was determined as 20 and a separate scoring key for an each worksheet was prepared. A sample scoring is demonstrated in Appendix. By using the scoring keys, the worksheets were evaluated. In statistical comparisons, Mann Whitney U Test for gender variable and Kruskall Wallis $\mathrm{H}$ Test for class variable were used.

3. Experience Determination Survey: A survey was prepared in order to determine the students' feelings for interactive non-formal chemistry environment and only had one question. This question was adapted from a study belonging to Wishart and Triggs (2010) and it is a word pool consisted of 21 positive words (various, useful, independent, interactive, 
enjoyable, explanatory, exciting, experience, different, amazing, team work, interesting, instructive, social, amusing, educational, excellent, important, creative, free, good) and 12 negative words (confusing, hard, boring, unnecessary, bad, loss of time, ordinary, vain, unplanned, complicated, impractical, meaningless). The students were asked to circle 5 words which expressed their feelings about the activities and to write the reason why they chose these words. In the analysis of experience determination survey, frequency value for each word circled by the students was calculated.

4. Interviews: After the treatment was completed, semi-structured interviews were carried out with one student from each grade, a total of 3 students so as to evaluate the process. In the interview, four questions were asked about the relationship between daily life activities and the setting used in the present study. Each interview took approximately 10-15 minutes and recorded with tape recorder. Initially, in the analysis process, codes were determined. Then the themes by grouping codes were formed. The themes and codes are given in the Table 6 .

\subsection{Design of Environment and Procedure}

First, 16 activities which are remarkable and relevant to daily life were chosen from different sources (from web sites, sample activity books, national and foreign chemistry books). A survey having a short demonstration of these activities was prepared and handed out to 178 students randomly chosen from different classes. They were asked to list the activities in order of importance to them and to write the reason why they found them interesting. 7 activities were determined according to the preferences of students. These activities and chemistry concepts in each activity are given in Table 1.

Table 1 . Name of the activity and relevant chemistry concepts

\begin{tabular}{|c|c|c|c|}
\hline $\begin{array}{l}\text { Activity } \\
\text { No }\end{array}$ & Activity name & Relevant concepts & Time \\
\hline 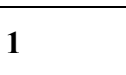 & 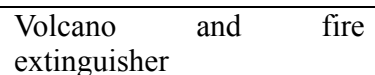 & Acidic-basic substances; $\mathrm{pH}$; indicator & $30 \mathrm{~min}$ \\
\hline 2 & A yellow from two whites & Precipitating reactions & $25 \mathrm{~min}$ \\
\hline 3 & Making ice-cream & $\begin{array}{l}\text { Colligative characteristics; freezing point depression; } \\
\text { boiling point elevation }\end{array}$ & $35 \mathrm{~min}$ \\
\hline 4 & Jumping sodium & Activity of metals & $25 \mathrm{~min}$ \\
\hline 5 & Making soap & Soap and detergent; hard and soft water & $34 \mathrm{~min}$ \\
\hline 6 & Elephant's toothpaste & Factors affecting reaction rate; catalyzer & $26 \mathrm{~min}$ \\
\hline 7 & Making glue & Polymerization; natural and artificial polymer & $33 \mathrm{~min}$ \\
\hline
\end{tabular}

After determining the activities, chemistry laboratory of a high school in Trabzon was reorganized for this study. Initially, 7 large activity tables were placed into the laboratory. Each activity was assigned to a table. A poster containing brief information and figures about intended activity was pasted on each table. Also required materials for the activities were put on the tables. In the process of designing the experimental environment and conducting activities of 7 student teachers of senior class in department of chemistry education helped the researcher. During the study, chemistry student teachers served as a counselor. The sample was informed about the study process and Chemistry Attitude Scale was applied as a pre-test. At the same time the activity booklet consisted of concepts and explanations about activity (activity materials, the structure of activity, and the aim of activity) was handed out to the sample. This booklet was prepared by the researcher. The student teachers were informed about the procedure created by the researcher for these activities. The study started one week after these procedures were implemented.

Students were divided into 4 groups consisted of 3 or 4 students in each group. Before each activity, the students were given brief information about the activity and materials to be used in the activity. Then the posters on the activity tables were drawn attention to and the concepts were discussed. After this step, the counselor of the table executed the activity with the students. After completing the activity, the concepts studied in the activity were summed up briefly by using the posters one more time. In each activity a similar route was taken. The study was completed in total of 3 days. Each activity took approximately 25-35 minutes. A week after the study Chemistry Attitude Scale and Experience Determination Survey were applied to the sample. In the following week the interviews were carried out with one student from each grade, making up a total of 3 participating students.

\section{Results}

In this part, findings obtained from Chemistry Attitude Scale, Experience Determination Survey, Worksheets and interviews are given in the specified order.

\subsection{Findings obtained from Chemistry Attitude Scale}

The means calculated for each item in pre- and post-tests and differences between pre- and pot-test means are given in Table 2. 
Table 2. Analysis of scale items

\begin{tabular}{|c|c|c|c|c|}
\hline \multicolumn{2}{|c|}{ Items of Scale } & \multirow{2}{*}{$\begin{array}{l}\text { Pre-test mean } \\
3,71\end{array}$} & \multirow{2}{*}{$\begin{array}{l}\begin{array}{l}\text { Post-test } \\
\text { mean }\end{array} \\
4,71\end{array}$} & \multirow{2}{*}{$\begin{array}{l}\begin{array}{l}\text { Mean } \\
\text { Difference } \\
(+/-)\end{array} \\
+1,00\end{array}$} \\
\hline \multirow{13}{*}{ 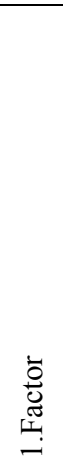 } & 1. Chemistry courses are enjoyable. & & & \\
\hline & 2. I do not like chemistry. & 3,21 & 3,79 & $+0,58$ \\
\hline & 3. Chemistry is easy for me. & 4,14 & 3,86 & $-0,28$ \\
\hline & 4. I do not like chemistry course. & 3,57 & 3,93 & $+0,36$ \\
\hline & 5. I have a positive attitude towards chemistry. & 3,86 & 4,43 & $+0,57$ \\
\hline & 6. To know chemistry is important so as to have a good job. & 3,36 & 3,36 & 0,00 \\
\hline & 7. Chemistry is necessary for dealing with the problems of daily life. & 3,29 & 4,36 & $+1,07$ \\
\hline & 8. I am looking forward to chemistry courses. & 3,29 & 3,43 & $+0,14$ \\
\hline & 9. Chemistry is one of the most interesting courses. & 3,50 & 3,79 & $+0,29$ \\
\hline & 10. Chemistry does not draw my interest. (negative sentence) & 4,14 & 4,79 & $+0,65$ \\
\hline & 11. Chemistry courses bore me. (negative sentence) & 3,64 & 4,14 & $+0,50$ \\
\hline & 12. I am not good at chemistry. (negative sentence) & 3,29 & 4,00 & $+0,71$ \\
\hline & 13. I do not understand chemistry in any way. (negative sentence) & 3,57 & 3,71 & $+0,14$ \\
\hline \multirow{7}{*}{ 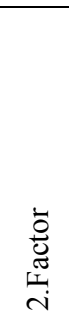 } & 14. To study in laboratory might be a beautiful way of earning a living. & 4,14 & 4,29 & $+0,15$ \\
\hline & $\begin{array}{l}\text { 15. After graduation, I want to work with people making chemistry } \\
\text { discoveries. }\end{array}$ & 3,21 & 4,00 & $+0,79$ \\
\hline & 16. I love dealing with chemistry projects. & 4,00 & 3,71 & $-0,29$ \\
\hline & 17. After graduation, I want to be a scientist. & 3,14 & 4,21 & $+1,07$ \\
\hline & $\begin{array}{l}\text { 18. After graduation, I do not want to work in chemistry laboratory. (negative } \\
\text { sentence) }\end{array}$ & 3,43 & 3,71 & $+0,28$ \\
\hline & 19. Being a scientist may be boring. (negative sentence) & 4,07 & 4,57 & $+0,50$ \\
\hline & 20. Making a career in chemistry is routinized and boring. (negative sentence) & 3,86 & 4,43 & $-0,57$ \\
\hline
\end{tabular}

As can be seen in Table 2, while pre-test means range from 3.14 to 4.14, post-test means range from 3.36 to 4.79 . Also the scaling items which have the highest mean increase from pre-test to post-test are 'Chemistry courses are enjoyable (Item 1)', 'Chemistry is necessary for dealing with the problems of daily life (Item 7)', and 'After graduation, I want to be a scientist. (Item 17)', the scaling item which does not have any mean change is ' To know chemistry is important so as to have a good job (Item 6)' (Table 2). A decrease was observed in the items 'Chemistry is easy for me (Item 3)' and 'I love dealing with chemistry projects (Item 16)'. The pre- and post-test means and standard deviations of the scale sub-factors and results of Wilcoxon Signed Rank Test for both factors were given in Table 3.

Table 3. Means and standard deviation values of the scale' sub-factors, and results of Wilcoxon Signed Rank Test

\begin{tabular}{lllllll}
\hline \multirow{2}{*}{ Factors } & \multicolumn{2}{c}{ Pre-test } & \multicolumn{3}{c}{ Post-test } & \multicolumn{2}{c}{ Wilcoxon } \\
\cline { 2 - 7 } & Mean & SD & Mean & SD & z & $\mathrm{p}$ \\
\hline Factor 1 & 3.58 & 0.31 & 4.02 & 0.44 & 2.39 & .017 \\
Factor 2 & 3.69 & 0.42 & 4.13 & 0.34 & 2.67 & .008 \\
\hline
\end{tabular}

As seen in Table 3, the mean of both factors from pre-test to post-test increased approximately 0.40 . Whether the increase was statistically significant or not is determined with Wilcoxon Signed Rank Test. The difference between the means of the pre-test and post-test obtained from the scale's 1 st sub-factor was statistically found significant $(\mathrm{z}=2.394$; $\mathrm{p}<.05)$. Similarly the difference between the means of $2 \mathrm{nd}$ sub-factor was found significant, as well $(\mathrm{z}=2.670 ; \mathrm{p}<.05)$.

The results obtained from the attitude scale were evaluated by using Mann Whitney U Test in terms of gender and class level variables. The results of Mann Whitney U Test indicated that the students' pre-attitudes were similar in terms of gender or class level ( $\mathrm{p}>.05)$.

\subsection{Findings of Experience Determination Survey}

The data obtained from Experience Determination Survey in order to determine the effect of interactive non-formal chemistry environment on students' feelings, are given in Table 4.

As can be seen in Table 4, students preferred 17 positive and 1 negative words so as to describe the environment. The most preferred words were enjoyable (6), amusing (6), experience (6), different (5), amazing (5), team work (5), interesting (5) and instructive (5). The least preferred ones were social (1), important (1), and confusing (1). None of the students preferred the other words in the survey. Hence it inferred that students have positive sentiments about the experimental environment. Some of the reasons why the students chose the words in Table 4 were given below.

'The activities are instructive and easy because they teach what exists and why exists' (9B1). 'Also the activities such as soft soap, ice-cream, etc. are useful for human life' (11B2). 'We had useful information when the activities correlated concepts with daily life' (11G2). 'We learned formulas of some compounds. These were important for us' (9B3). 'The activities which we did with team work helped us a lot so as to understand and interpret chemistry' (10K2). 
'While doing these activities I enjoyed a lot. I learned new things. It became an important experience for me' (10G1). 'Doing the activities freely without any restriction was enjoyable' (11B3). 'Interacting with activities was really enjoyable' (9B2). 'My friends and I had a great time with the activities because I have never been in such activity before' (11B2). 'By mixing different substances, getting different substances after reaction was amazing' (11G2). 'I enjoyed doing some activities' (10B2). 'With different colors, with bubbles, exciting and interesting' (9B1). 'I was confused in some activities. Of course, I had some questions on my mind. Probably because I do not have chemistry background.' (10G1) 'With different activities I understood the importance of experiment in science' (11B3). 'We offered diversity by doing activities within the experiment' (10B3).

Table 4. The data obtained from Experience Determination Survey

\begin{tabular}{lll}
\hline Words & Student Code & $\begin{array}{l}\text { Frequency } \\
\text { (f) }\end{array}$ \\
\hline Different & $11 \mathrm{~B} 3,10 \mathrm{~B} 2,9 \mathrm{~B} 3,9 \mathrm{G} 1,10 \mathrm{~B} 1$ & 5 \\
Various & $11 \mathrm{~B} 3,10 \mathrm{~B} 3,10 \mathrm{~B} 1$ & 3 \\
Experience & $10 \mathrm{G} 1,11 \mathrm{~B} 2,11 \mathrm{~B} 3,10 \mathrm{G} 2,10 \mathrm{~B} 3,11 \mathrm{~B} 1$ & 6 \\
Teamwork & $10 \mathrm{~B} 2,10 \mathrm{G} 2,9 \mathrm{~B} 3,10 \mathrm{~B} 3,11 \mathrm{~B} 1$ & 5 \\
Social & $11 \mathrm{~B} 3$ & 1 \\
Free & $11 \mathrm{~B} 3,11 \mathrm{~B} 1,11 \mathrm{G} 1,9 \mathrm{G} 1$ & 4 \\
Interactive & $9 \mathrm{~B} 1,9 \mathrm{~B} 2$ & 2 \\
Enjoyable & $10 \mathrm{G} 1,11 \mathrm{~B} 2,11 \mathrm{G} 2,9 \mathrm{~B} 2,9 \mathrm{~B} 1,10 \mathrm{G} 2,10 \mathrm{~B} 3,11 \mathrm{G} 1$ & 8 \\
Exciting & $10 \mathrm{~B} 1,9 \mathrm{G} 1,10 \mathrm{~B} 2,9 \mathrm{~B} 1,9 \mathrm{~B} 3$ & 2 \\
Interesting & $11 \mathrm{~B} 2,11 \mathrm{G} 2,10 \mathrm{5}$ \\
Amazing & $10 \mathrm{G} 1,11 \mathrm{G} 2,10 \mathrm{~B} 2,9 \mathrm{G} 1,11 \mathrm{G} 1$ & 5 \\
Amusing & $10 \mathrm{G} 1,10 \mathrm{~B} 2,9 \mathrm{~B} 2,10 \mathrm{G} 2,9 \mathrm{~B} 3,11 \mathrm{~B} 2$ & 6 \\
Instructive & $11 \mathrm{G} 2,10 \mathrm{G} 2,9 \mathrm{~B} 1,9 \mathrm{G} 1,11 \mathrm{G} 1$ & 5 \\
Useful & $11 \mathrm{~B} 2,11 \mathrm{G} 2,9 \mathrm{~B} 2,10 \mathrm{~B} 1$ & 4 \\
Explanatory & $9 \mathrm{~B} 1,11 \mathrm{~B} 1,11 \mathrm{G} 1,10 \mathrm{~B} 1$ & 4 \\
Important & $11 \mathrm{~B} 1$ & 1 \\
Educational & $9 \mathrm{~B} 2,9 \mathrm{~B} 3,10 \mathrm{~B} 3$ & 3 \\
Confusing & $10 \mathrm{G} 1$ & 1 \\
\hline
\end{tabular}

\subsection{Data of Worksheets}

This part summarizes the data obtained from the analysis of worksheets. Table 5 shows the students' points and means obtained from each worksheet.

Table 5. Students' points and means for each worksheet

\begin{tabular}{lllllllll}
\hline Student Code & $\boldsymbol{W 1}$ & $\boldsymbol{W 2}$ & $\boldsymbol{W 3}$ & $\boldsymbol{W 4}$ & $\boldsymbol{W 5}$ & $\boldsymbol{W 6}$ & $\boldsymbol{W 7}$ & Mean \\
9G1 & 12 & 10 & 10 & 14 & 12 & 8 & 15 & 11,6 \\
9B1 & 16 & 6 & 16 & 15 & 11 & 10 & 12 & 12,3 \\
9B2 & 20 & 15 & 16 & 17 & 20 & 16 & 20 & 17,7 \\
9B3 & 13 & 8 & 12 & 8 & 7 & 14 & 10 & 10,3 \\
Mean & $\mathbf{1 5 , 2 5}$ & $\mathbf{9 , 7 5}$ & $\mathbf{1 3 , 5}$ & $\mathbf{1 3 , 5}$ & $\mathbf{1 2 , 5}$ & $\mathbf{1 2}$ & $\mathbf{1 4 , 2 5}$ & $\mathbf{1 3 , 0}$ \\
\hline 10B1 & 15 & 12 & 14 & 14 & 15 & 17 & 13 & 14,3 \\
10B3 & 15 & 10 & 14 & 14 & 13 & 12 & 13 & 13,0 \\
10G2 & 13 & 12 & 15 & 9 & 10 & 14 & 10 & 11,9 \\
10G1 & 8 & 14 & 5 & 11 & 8 & 13 & 15 & 10,6 \\
10B2 & 12 & 9 & 15 & 17 & 14 & 15 & 18 & 14,3 \\
Mean & $\mathbf{1 2 , 6}$ & $\mathbf{1 1 , 4}$ & $\mathbf{1 2 , 6}$ & $\mathbf{1 3}$ & $\mathbf{1 2}$ & $\mathbf{1 4 , 2}$ & $\mathbf{1 3 , 8}$ & $\mathbf{1 2 , 8}$ \\
\hline 11B2 & 19 & 6 & 12 & 18 & 11 & 10 & 15 & 13,0 \\
11B1 & 16 & 10 & 16 & 15 & 9 & 7 & 18 & 13,0 \\
11G1 & 10 & 10 & 11 & 12 & 13 & 12 & 15 & 11,9 \\
11G2 & 17 & 15 & 19 & 18 & 8 & 16 & 12 & 15,0 \\
11B3 & 18 & 12 & 12 & 16 & 6 & 11 & 18 & 13,3 \\
Mean & $\mathbf{1 6}$ & $\mathbf{1 0 , 6}$ & $\mathbf{1 4}$ & $\mathbf{1 5 , 8}$ & $\mathbf{9 , 4}$ & $\mathbf{1 1 , 4}$ & $\mathbf{1 5 , 6}$ & $\mathbf{1 3 , 3}$ \\
\hline Total Mean & 14,2 & 14,2 & 13,4 & 14,1 & 11,2 & 12,5 & 14,6 & 13,5 \\
(out of 100) & $(72,8)$ & $(70,9)$ & $(66,8)$ & $(70,7)$ & $(56,0)$ & $(62,5)$ & $(\mathbf{7 2 , 8})$ & $(67,5)$ \\
\hline
\end{tabular}

*W=worksheet; $\mathrm{B}=$ boy; $\mathrm{G}$ : girl

As can be seen in Table 5, the students reached the highest success with a rate of $72.8 \%$ from 1 st and 7 th worksheets, the lowest success with a rate of $56 \%$ from 5th worksheet. In total, the most successful student was 9B2 (17.7), the most unsuccessful student was 9B3 (10.3) from 9th graders. General success rate $67.5 \%$ can be seen in Table 5. In each activity, the means of students in different grade levels are quiet close. Only in activity 5 , an important decrease can be seen in the results of 11 th graders. Furthermore, the means of 11th graders have sharp drop and rise (Table 5). In terms of gender which was another variable of the study, the students' performances were given in Figure 1. 


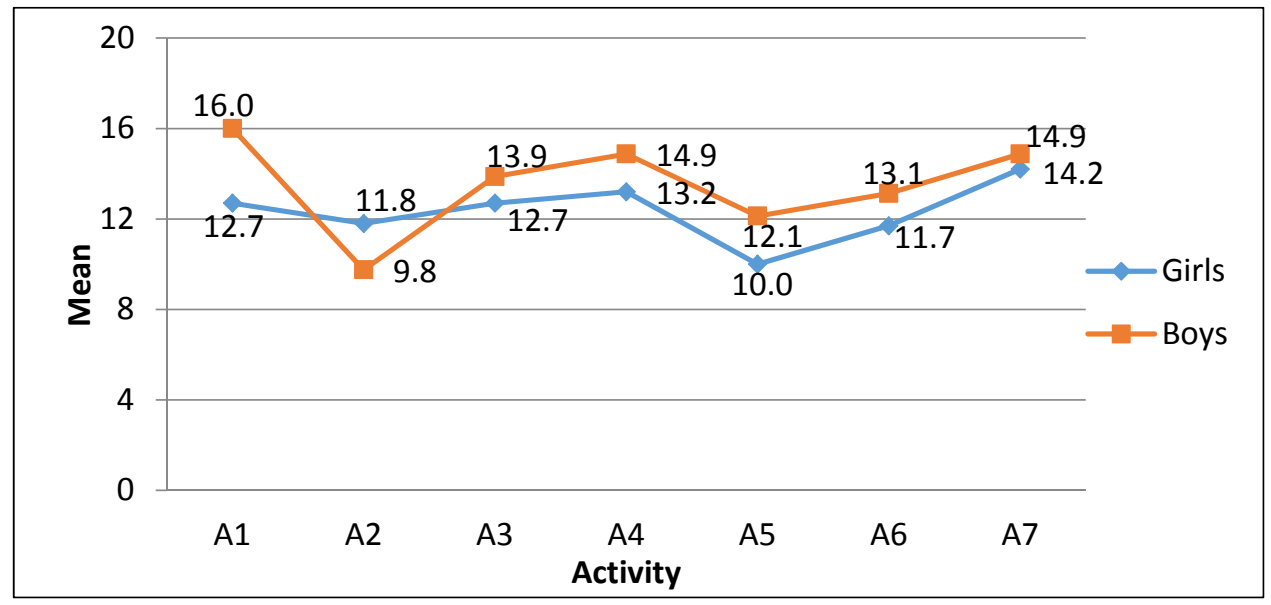

Figure 1. The students' performances in worksheets according to gender

As can be seen in Figure 1, except for 2nd worksheet, boys have higher performances. Mann Whitney U Test indicated that there is no statistically significant difference between boys and girls ( $p>.05)$. Similarly Kruskal Wallis H Test showed that there are no statistically significant differences among grade levels of the students ( $>$ >.05).

\subsection{Findings of Interviews}

The data obtained from interviews with 9B2, 10G2 and 11B2 coded students is given in Table 6 .

Table 6. Analysis of interviews

\begin{tabular}{|c|c|c|c|}
\hline Main Titles & Themes & $\mathbf{f}$ & Student explanation \\
\hline \multirow{3}{*}{$\begin{array}{l}\text { Daily life and } \\
\text { chemistry }\end{array}$} & \multirow{3}{*}{$\begin{array}{l}\text { Correlating } \\
\text { daily life }\end{array}$} & \multirow[b]{3}{*}{1} & Making soft soap (11B2, 9B2) \\
\hline & & & Making ice-cream experiment (11B2, 10G2) \\
\hline & & & $\begin{array}{l}\text { It contributed to my interpretation about daily life events } \\
\text { (10G2) }\end{array}$ \\
\hline \multirow{3}{*}{$\begin{array}{l}\text { Attitude towards } \\
\text { chemistry }\end{array}$} & intriguing & \multirow[b]{2}{*}{1} & Activities are quiet intriguing (11B2) \\
\hline & enjoyable & & $\begin{array}{l}\text { Enjoyable activities provided me to gain positive attitude } \\
\text { (10G2) }\end{array}$ \\
\hline & interesting & 1 & We performed interesting activities (9B2) \\
\hline \multirow{4}{*}{$\begin{array}{l}\text { Interesting } \\
\text { experiment }\end{array}$} & $\begin{array}{l}\text { One yellow from } \\
\text { two whites }\end{array}$ & \multirow{2}{*}{$\begin{array}{l}3 \\
1\end{array}$} & $\begin{array}{l}\text { Combining two white solutions that produce one yellow } \\
\text { precipitate drew my interest } \\
(10 \mathrm{G} 2,11 \mathrm{~B} 2,9 \mathrm{~B} 2)\end{array}$ \\
\hline & $\begin{array}{l}\text { Volcano } \\
\text { experiment }\end{array}$ & & Kneading dough was enjoyable (10G2) \\
\hline & \multirow[t]{2}{*}{ Soap experiment } & \multirow{2}{*}{2} & $\begin{array}{l}\text { We often use soap. I found how it is made interesting } \\
\text { (9B2). }\end{array}$ \\
\hline & & & $\begin{array}{l}\text { Combining liquid solutions that produce a solid drew my } \\
\text { interest(11B2) }\end{array}$ \\
\hline \multirow{3}{*}{$\begin{array}{l}\text { Suggestions } \\
\text { about the setting }\end{array}$} & \multirow{3}{*}{ Time and place } & \multirow[t]{3}{*}{2} & $\begin{array}{l}\text { Personally doing by touching is more } \\
\text { permanent }(9 \mathrm{~B} 2) \text {. }\end{array}$ \\
\hline & & & More detailed activities (11B2) \\
\hline & & & $\begin{array}{l}\text { I think that computer games will contribute to the setting } \\
\text { (10G2) }\end{array}$ \\
\hline
\end{tabular}

The first question of interview is 'were the activities in interactive non-formal chemistry environments effective on correlating chemistry with daily life? Can you give an example?' All the selected students (3) stated that the activities carried out were effective on correlating chemistry with daily life. The effect was based on the soft soap and ice-cream activities by the students (Table7). 11B2 coded student answered the question: ' ....for example not sodium blasting, I'm just saying but for example soft soap. How do we get those soaps? How are they made? Well, the techniques were effective or ice-cream, you know. Well, do ice-cream makers make them just like that? But this technique was good, too. Potassium, you know, is more relevant to chemistry; It is not used much in everyday life.'

The second question of interview was ' Were the interactive non-formal chemistry environment effective on your attitude towards chemistry?' All the interviewees (3 students) stated that it had positive effects. 10G2 coded student answered this question as follows:

'Yes, well. Generally people see chemistry as a boring course. You know the experiments. I think that chemistry is a complicated course but I have so much fun doing activities, now I think positive about chemistry.' 
The third question of interview is ' Which one was the most interesting among the activities for you? Can you explain the reason?' Table 7 summarizes the students' answers. 9B2 coded student' answer was given below:

In the "yellow precipitate experiment", there were two different white substances. We dissolved these in water. After mixing up these, they are making bonds. 'Less soluble one precipitates. Well, it drew my interest. Also making soap activity is interesting. We use soap too much. Learning how it was made attracted my attention.'

The fourth question of interview is 'what else could be done in order to make the activities more interesting? Do you have suggestions?' Table 7 shows the students' answers for this question and 11B2 coded student's interview was given as a dialogue below:

Researcher: Well, in your opinion, what else could be done in order to make our activities and the environment more interesting? Do you have suggestions?

11B2: Rather than the environment itself, being prepared to experiment is important for students... In the experiments on the first day we cannot understand purpose of the experiments, you witnessed, too. Prior to the treatment, student should be given information about the activities. For example, more comprehensive experiments should be given. Activities containing more materials and from which we could get different things would be better.

Researcher: Ok, in your opinion how could the environment be improved? For example, could it be more effective if there were computer games? Or what else could be added?

11B2: The environment... We conducted the experiments in chemistry laboratory. It could have been more comfortable and different.

Researcher: Could it be more effective if it was out-of-school?

11B2: I can hardly concentrate. Well, 1 cannot conduct those activities outdoors. It must be closed and large place. I am not interested in computer games as you said, I am realistic, and you know maybe it could be effective for kids.

\section{Discussion}

In this study, the effect of an interactive non-formal chemistry environment on students' attitudes towards chemistry and skills of correlating chemistry concepts with daily life were investigated. With this objective in mind, primarily it was searched how this type of environment must be designed and what features of activities must be part of setting. Then, the present study was done at a high school's chemistry laboratory. In non-formal interviews conducted with students, it was determined that they had not used the laboratory before. The laboratory was prepared as interesting as possible. The results indicated that the prepared environment were considerably effective on students' attitudes. The findings obtained from 1st sub-factor of Chemistry Attitude Scale showed that the activities caused a notable increase in students 'attitudes towards chemistry. Excluding the 3rd and 6th items, research results indicate an increase at varying rates (Table 2). On average, it is observed that the effectiveness of 1st item (Chemistry courses are enjoyable) and 7th item (Chemistry is necessary for dealing with the problems of daily life) increased most. When analyzed in detail, it was understood that these two items reflected the main theme to be given in the non-formal chemistry environment. In the study, students experienced some cases which they encountered in daily life and they could not understand their reasons. The studies in the literature have indicated that the visits to interactive non-formal learning environments provided an increase of students' attitudes towards their fields of interest and created curiosity within students (Falk \& Adelman (2003; Daneshamooz et al., 2013; Ornstein, 2006; Wigg, 1995; Gibson \& Chase, 2002). The results of the Attitude Scale used in the present study strongly support the results of studies in the literature. The findings obtained from 2 nd sub-factor of Attitude Scale indicate that the environment affected the students' career planning in chemistry or being a scientist $(\mathrm{p}<.05)$. Within 3 days, the observed change in students' career perception is really astonishing and encouraging the usage of such learning environments. The activities used in the study have an important effect on the success of the experimental setting because most of the activities were conducted by using daily life materials and supplies. For example, vinegar and carbonate for volcano experiment; milk, cream and salt for ice-cream experiment; water, flour, sugar and carbonate for making glue experiment were used. The product of the activity such as making soap experiment is relevant to daily life. Before the activities, the students could not understand how these materials would be used in the experiments. As the time progressed, it was observed that they asked the questions 'We wonder if different materials can be used?' The studies indicated that generally informal learning environments and activities in these environments would make chemistry course interesting and enjoyable (Falk \& Adelman, 2003; Ducci, 2005; Tenenbaum et al., 2004). Ducci (2005) used food stuffs (lemon, jelly candy, raspberry) as indicators in students' experiments which he designed and got successful results. When the findings of Experience Determination Test were evaluated, it was observed that after the practice in interactive non-formal chemistry environment, the students had positive experiences. It can be indicated that mostly selected words were positive, unselected words were negative. Falk and Dierking (2013) in their study conducted a survey with the adults visiting California Science Center. The results 
indicated that $95 \%$ of participants understood science and technology better, interest of many participants (92\%) on science and technology increased, and 94\% of participants learned something new about science and technology. As is seen, the results of experience determination test support the results of attitude scale. One of the environment's main objectives is to determine the students' level of correlating chemistry concepts with daily life. General average of worksheets is $67.5 \%$. It can be said that general average was quite good when considered the environment not having a sample even if it was not high and designed such environment for the very first time. The environment was supposed to be more effective if it was taken as a booth in a wide ranging science center. According to class level, general averages of worksheets were calculated as 13.0 for 9th grade; 12.8 for 10 th grade; 13.3 for 11 th grade. As is seen, the average points of groups are very close and the differences between them are not statistically meaningful. Since the students' class levels are different, their preconception and background can be accepted as different, as well. However it is interesting that there is no difference between their knowledge and skills which they obtained from the environment. Similarly the students' performances on worksheets did not show any meaningful difference in terms of gender.

It was determined from the analysis of worksheets; students had higher success in the activities related to daily life. This finding is consistent with the results of previous studies in literature (Bennett, 2003; Gilbert, 2006; Gilbert et al., 2011; Milner et al., 2010). Also interviewees' performances in worksheets were compared to their scores. For example, 9B2 coded student stated that 5 th and 7th activities were the most interesting experiments for him and he had an overachievement on worksheets about these activities. Although 11B2 coded student stated that making ice-cream activity was effective on correlating chemistry with daily life, he got 12 points from this activity's worksheet. 10G2 coded student stated that 5th activity was the most interesting but in this activity she was unable to get a high score. Ertaş et al. (2011) in their study, aimed to determine the effects of out-of-school scientific activities on students' level of correlating 'Energy' subject with daily life. The results indicated that 58 students' levels of understanding and correlating 'Energy' subject with daily life increased.

Koçak (2011), in his study, determined that daily life chemistry themed activities designed according to the 5E model, provided positive increase in 9th graders' skills of using the rudiments of Chemical Changes unit and correlating with daily life and their attitudes towards daily life chemistry. The data of interviews support the results of experience determination test. When the answers of interview questions are examined, it was observed that non-formal chemistry environment made important contributions to students' skills of using the knowledge about activities' concepts and correlating with daily life (Table 7). Also, it is understood that students' ideas about the environment and activities were positive, as well. This condition coincides with the results of attitude scale and experience determination test. Parchmann et al. (2006) determined that students who visited similar environments improve their motivation towards more involvement with courses. They suggested that the reason of this motivation was that chemistry subjects are not only academic but also they are relevant to real life subjects. From this, it can be said that when students realize that chemistry is not restricted to class and laboratory and an important part of everyday life, their success, interest and motivation increase.

\section{Conclusions and Recommendations}

In this study, activities about particular subjects of chemistry were designed and conducted in a non-formal environment with 14 high school students. Furthermore, students' level of attitudes towards chemistry before and after the treatment, their views about the treatment and activities, and their association levels of chemistry concepts with daily life were investigated. This study is limited again by the small sample size (14 students), and by one group. The results should be evaluated taking into account the limitations.

A statistically significant difference between the students' pre-test points and post-test points of chemistry attitude scale was found. This result shows that non-formal chemistry environment is effective on students' attitudes towards chemistry and future career plans. From this point of view, it was deduced that non-formal chemistry environments organized by using daily life events can create a change in students' attitudes and career plans. The findings of experience determination survey and interviews support this result, as well. With $67.5 \%$ mean, it was seen that non-formal chemistry environments made important contributions to the students' knowledge about the concepts in activities and their skills of correlating these concepts with daily life. Students' achievement in the worksheets without having anxiety for marks is promising for these kinds of non-formal environments' future. The findings of worksheets indicated that with some exceptions students were more successful in more related activities with daily life. This result was supported with interviews, as well. Different types and difficulty levels of questions can be the reason of the exceptions. Also the number of chemistry concepts in the study could have affected the students' performances. For this reason, evaluating the environment by comparing the points obtained from worksheets about different concepts, cannot give accurate results. The effect of the environment on the attitude did not differ in terms of class level and gender. Hereby, it was deduced that the environment was not boring and it could make similar contributions to individuals having different background. The environment being able to make contributions to students having different 
backgrounds is an extremely important and remarkable result. In reaching this result, the students being volunteer and more unrestricted than classroom environment have been effective. Also the concepts which are related to daily life may contribute to this result. While evaluating the results in terms of gender and class variable, it should not be forgotten that the sample size were quite insufficient for statistical comparisons. However they inspired significant ideas for future studies. In this study, based on chemistry should be taught in non-formal environment by associating daily life with concrete observations and efforts, activities related to daily life were carried out in a non-formal environment and it was deduced that these kinds of environments had effect on students 'attitudes towards chemistry and correlating chemistry with daily life. The results of research showed that the intended objectives were achieved. Based on the results, some suggestions were made:

The activities in non-formal learning environments may be supported with different teaching methods and technics (computer assisted instruction, using creative drama, etc.) in order to achieve the aims determined by counselors and teachers, beyond the entertainment.

The sample of this research consisted of 14 students. It can be done similar studies with large numbers of samples, to obtain more reliable outcomes.

The results obtained from the study indicated that there was a positive increase in high school students' attitudes towards chemistry. The results of similar environments can be evaluated by designing for other class and age levels, as well (for primary education, university, adults). Also both primary and elementary education students should be motivated to visit non-formal learning environments.

In this study the effects of activities on students 'attitudes, comprehension and levels of correlating concepts with daily life were examined. It can be examine students' anxiety, self-sufficiency, etc. in other studies, as well.

This study was designed for some subjects of chemistry. Similar studies should be conducted in other chemistry and science subjects in order to collect more evidence about the teaching approach used in the present study.

In the present study 'Interactive Non-formal Chemistry Environment' was created in chemistry laboratory of a high school. In further studies, it is suggested that such environments are organized in a suitable place away from the school. This will be much more striking and different for students. Furthermore having a wide place allows to do different sportive and artistic activities in their breaks.

Within the scope of this study, interviews were made with students after the visit of interactive non-formal chemistry environment. In a similar study, interviews can be done both before and after the practice because the change in students' views can be determined clearly.

Chemistry teachers should be encouraged to attend in-service training in order to organize similar environments in their schools and to take their students to non-formal learning environments.

There are hardly any studies in our country, which examines the contributions of non-formal learning environments to chemistry teaching. For this reason, the studies associating out-of-school learning environments with chemistry courses should be conducted and new chemistry teaching programs should encourage the use of non-formal learning environments.

\section{References}

Anagün, Ş. S., Ağır, O., \& Kaynaş, E. (2010). İlköğretim öğrencilerinin fen ve teknoloji dersinde öğrendiklerini günlük yaşamlarında kullanım düzeyleri. 9. Ulusal Sınıf Öğretmenliği Sempozyumu, Elazığ.

Armağan, B. (2015). İlkokul dördüncü sınıf fen öğretiminde okul dışı öğrenme ortamları: Bir eylem araştırması. Unpublished Master's Thesis, University of Dokuz Eylül, İzmir.

Balkan-Kıyıcı, F. (2008). Fen bilgisi öğretmen adaylarının günlük yaşamları ile bilimsel bilgileri ilişkilendirebilme düzeyleri ve bunu etkileyen faktörlerin belirlenmesi. Unpublished Doctoral Dissertation, Gazi University, Ankara.

Barke, H. D. (1987). Chemie erscheint nicht so sinnlos, wenn man den stoff auch im alltag anwenden kann. In: Lindemann, H NiU-PC, 35. Jg. H. 25, 38-40.

Bennett, J. (Ed.). (2003). Teaching and learning science, London, UK: Continuum

Boisvert, D. L., \& Slez, B. J. (1994). The relationships between visitor characteristics and learning-associated behaviours in a science museum discovery space. Science Education, 78(2), 137-148. http://dx.doi.org/10.1002/sce.3730780203

Bozdoğan, A. E. (2007). Bilim ve teknoloji müzelerinin fen öğretimindeki yeri ve önemi, Unpublished Doctoral Dissertation, Gazi University, Ankara. 
Bulte, A. M. W., Westbroek, H. B., De Jong, O., \& Pilot, A. (2006). A research approach to designing chemistry education using authentic practices as contexts. International Journal of Science Education, 28(9), 1063-1086. http://dx.doi.org/10.1080/09500690600702520

Cedefop (2008). The shift to learning outcomes in European education and training policies and practises, The European Centre for the Development of Vocational Training (Cedefop), Thessaloniki.

Coştu, B., Ünal, S., \& Ayas, A. (2007). Günlük yaşamdaki olayların fen bilimleri öğretiminde kullanılması. Kırşehir Ë̆itim Fakültesi Dergisi, 8(1), 197-207.

Creswell, J. W. (2013). Research design: Qualitative, quantitative, and mixed methods approaches (4nd ed.). Thousand Oaks, CA: Sage.

Daneshamooz, S., Alamolhodaei, H., Darvishion, S., \& Daneshamooz, S. (2013). Science center and attitude. Educational Research and Reviews, 8(19), 1875-1881.

Demircioğlu, G., Aslan, A., \& Yadigaroğlu, M. (2013). Exploratory factor analysis study for the scale of high school students' attitudes towards chemistry, WCEIS, International Journal on New Trends in Education and Their Implications, 5(1), 38-45.

Demircioğlu, H., \& Atasoy, Ş. (2006). Çalışma yapraklarının geliştirilmesine yönelik bir model önerisi, Dokuz Eylül Üniversitesi Buca Ĕgitim Fakültesi Dergisi, 19, 79.

Ducci, M. (2005). Himbeere, waldmeister oder doch zitrone? Die verwendung von brausepulver und gummibärchen als indikatoren. CHEMKON, 12(4),171-173. http://dx.doi.org/10.1002/ckon.200510032

Ertaş, H., Şen, A. I., \& Parmaksızoğlu, A. (2011). The Effects of out-of school scientific activities on 9th grade students' relating the unit of energy to daily life. Necatibey Faculty of Education Electronic Journal of Science and Mathematics Education, 5(2), 178-198.

Ertaş-Kılıç, H., \& Şen, A. İ. (2014). The effect of physics education based on out-of-school learning activities and critical thinking on students' attitudes. Education and Science, 39(176), 13-30.

Eshach, H. (2007). Bridging in-school and out-of-school learning: formal, non-formal, and informal education. Journal of Science Education and Technology, 16(2), 171-190. http://dx.doi.org/10.1007/s10956-006-9027-1

Falk, J. H., \& Adelman, L. M. (2003). Investigating the impact of prior knowledge and interest on aquarium visitor learning. Journal of Research in Science Teaching, 40(2), 163-176. http://dx.doi.org/10.1002/tea.10070

Falk, J. H., \& Dierking, L. D. (2013). The Museum Experience Revisited. Walnut Creek, CA: Left Coast Press.

Gerber, B. L., Anne M., Cavallo, L., \& Marek, E. (2001). Relationships among informal learning environments, teaching procedures and scientific reasoning ability. International Journal of Science Education, 23(5) 535-549. http://dx.doi.org/10.1080/09500690116971

Gibson, H. L., \& Chase, C. (2002). Longitudinal impact of an inquiry-based science program on middle school students' attitudes toward science. Science Education, 86, 693-705. http://dx.doi.org/10.1002/sce.10039

Gilbert, J. K. (2006). On the nature of context in chemical education. International Journal of Science Education, 28(9), 957-976. http://dx.doi.org/10.1080/09500690600702470

Gilbert., J. K., Bulteb, A. M. W., \& Pilot, A. (2011). Concept development and transfer in context-based science education. International Journal of Science Education, 33(6),817-837. http://dx.doi.org/10.1080/09500693.2010.493185

Gräber, W. (1992). Interesse am Unterrichtsfach Chemie, an Inhalten und Tätigkeiten. In: Chemie in der Schule, 39(10), 354-358.

Kee, T. P., \& McGovan, P. M. (1998). Chemistry within; chemistry without. Retrieved November, 12, 2014, from http://www.chem.vt.edu/confchem/1998/kee/kee.html

Kelly, L. (2002). "What is learning... and why do museums need to do something about it? Australian Museum University of Technology Seminars, Retrieved 22 November 2002, from http://www.amonline.net.au/amarc/pdf/research/lyndak.pdf

Koçak, C. (2011). Kimya konularının günlük yaşam konsepti çerçevesinde değerlendirilmesi. Doktora tezi, Hacettepe Üniversitesi, Ankara.

Kola-Olusanya, A. (2005). Free-choice environmental education: Understanding where children learn outside of school. Environmental Education Research, 11(3), 297-307. http://dx.doi.org/10.1080/13504620500081152 
Laçin, Ş. C. (2011). Fen Öğretiminde Okul Dışı Öğrenme Ortamları (1. Baskı). Ankara/ Pegem Akademi.

Martin, S. C. (2003). The influence of outdoor schoolyard experiences on students' environmental knowledge, attitudes, behaviors and comfort levels. Journal of Elementary Science Education, 15(2), 51-63. http://dx.doi.org/10.1007/BF03173843

MEB (2013). Talim ve terbiye kurulu başkanlı̆̆l, ortaöğretim kimya dersi (9, 10, 11 ve 12. Sinuflar) öğretim programı. Ankara: MEB Yayınları.

Meyveci, N. (1997). Bilgisayar Destekli Fizik Öğretiminin Öğrenci Başarısına ve Öğrencinin Bilgisayara Yönelik Tutumuna Etkisi, Yayınlanmamış yüksek lisans tezi, Ankara Üniversitesi, Ankara.

Milner, A. R., Templin, M. A., \& Czerniak, M. C. (2010). Elementary science students' motivation and learning strategy use: Constructivist classroom contextual factors in a life science laboratory and a traditional classroom. Journal of Science Teacher Education, 22(2), 151-170. http://dx.doi.org/10.1007/s10972-010-9200-5

Ornstein, A. (2006). The frequency of hands-on experimentation and student attitudes toward science: A statistically significant relation. Journal of Science Education and Technology, 15(3), 285-297. http://dx.doi.org/10.1007/s10956-006-9015-5

Osborne, J., \& Collins, S. (2001). Pupilsee views of the role and value of the science curriculum: a focus-group study. International Journal of Science Education, 23, 441-467. http://dx.doi.org/10.1080/09500690010006518

Parchmann, I., Gräsel, C., Baer, A., Nentwig P., Demuth, R., \& Ralle, B. (2006). Chemie im kontext: A symbiotic implementation of a context-based teaching and learning approach. International Journal of Science Education, 28(9), 1041-1062. http://dx.doi.org/10.1080/09500690600702512

Pınarbaş1, T., Doymuş, K., Canpolat, N., \& Bayrakçeken, S. (1998, Eylül). Üniversite kimya bölümü öğrencilerinin bilgilerini günlük hayatla ilişkilendirebilme düzeyleri. III. Ulusal Fen Bilimleri Sempozyumu, Trabzon.

Ramey-Gassert, L. (1997). Learning science beyond the classroom. The Elemantary School Journal, 97(4), 433-450. http://dx.doi.org/10.1086/461875

Reid, N. (2000). The presentation of chemistry logically driven or applications-led?, Chemistry Education: Research and Practice In Europe, 1(3), 381-392. http://dx.doi.org/10.1039/b0rp90018d

Soh, T. M., \& Mearah, T. S. (2013). Outdoor education: An alternative approach in teaching and learning science. Asian Social Science, 9(16), 1-8. http://dx.doi.org/10.5539/ass.v9n16p1

Sturm, H., \& Bogner, F. X. (2010). Learning at workstaitons in two different environments: A museum and a classroom. Studies in Educational Evaluation, 36(1-2), 14-19. http://dx.doi.org/10.1016/j.stueduc.2010.09.002

Taşdemir, A., \& Demirbaş, M. (2010). İlköğretim öğrencilerinin fen ve teknoloji dersinde gördükleri konulardaki kavramları günlük yaşamla ilişkilendirebilme düzeyleri. Uluslararası İnsan Bilimleri Dergisi, 7(1), 124-148.

Tenenbaum, H., Rappolt-Schlichtmann, G., \& Zanger, V. (2004). Children's learning about water in a museum and in the classroom. Early Childhood Research Quarterly, 19, 40-58. http://dx.doi.org/10.1016/j.ecresq.2004.01.008

The Physical Sciences Initiative (TPSI). (1991 June). Social and applied aspects what is meant by "social and applied"?, Retrieved November 12, 2013, from http://www.astc.org/about/index.htm. About ASTC. Association of Science Technology Centers October 10, 2014

Wellington, J. (1990). Formal and informal learning in science: the role of the interactive science centers. Physics Education, 25, 247-252. http://dx.doi.org/10.1088/0031-9120/25/5/307

Wigg, A. (1995). Improving the preschooler's science knowledge and skills through hands-on activities. Unpublished master thesis, Nova Southeastern University, Florida.

Wishart, J., \& Triggs, P. (2010). MuseumScouts: Exploring how schools, museums and interactive technologies can work together to support learning. Computers \& Education, 54, 669-678. http://dx.doi.org/10.1016/j.compedu.2009.08.034

Zoller, U. (1990). Students' misunderstandings and misconceptions in college freshman chemistry (general and organic). Journal of Research in Science Teaching, 27(10), 1053-1065. http://dx.doi.org/10.1002/tea.3660271011 


\section{Appendix}

Appendix. The worksheet 7 and scoring

YAPIŞKAN YAPMA DENEYINE YÖNELUK ÇALIŞMA KAĞıDI
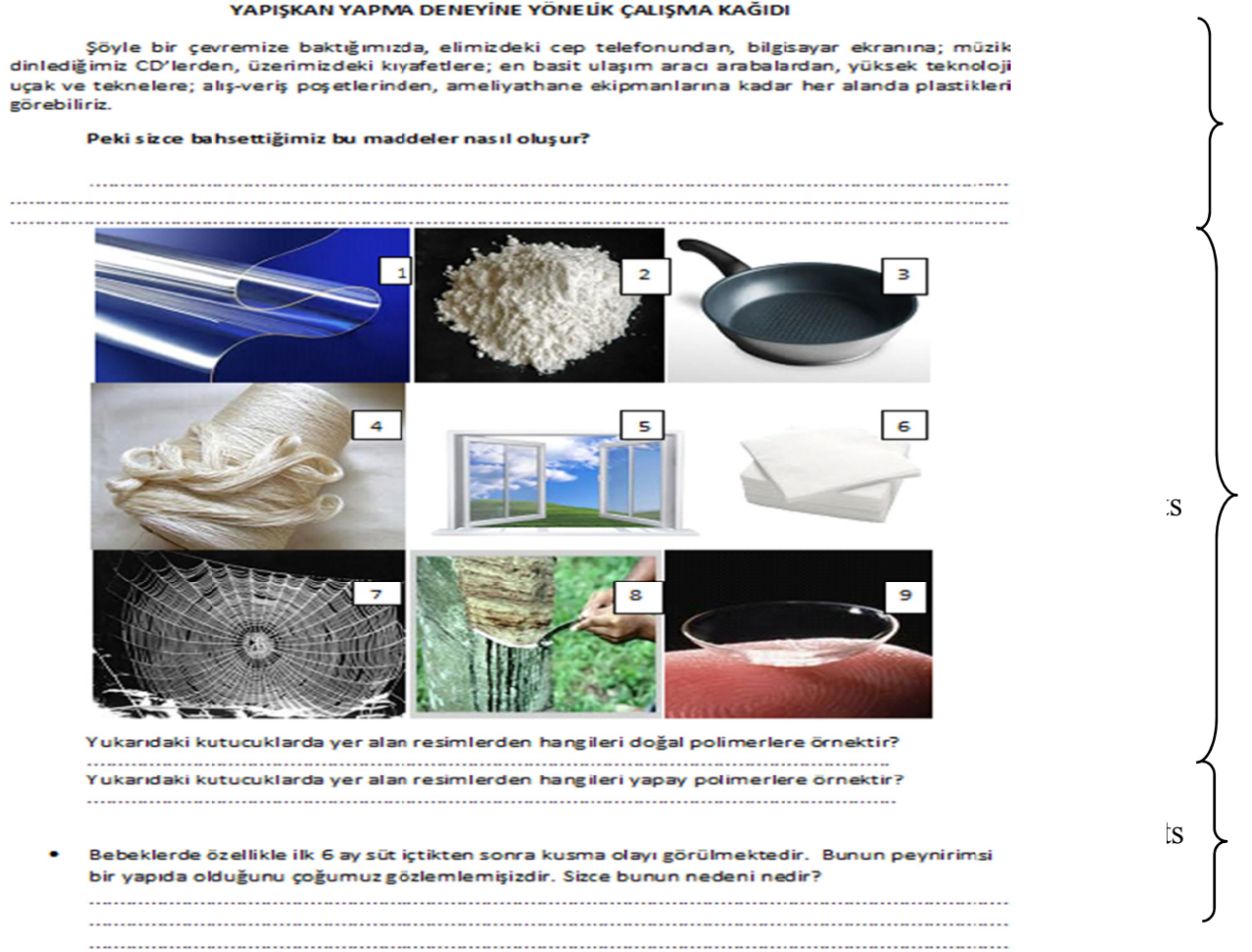

\section{(cc) EY}

This work is licensed under a Creative Commons Attribution 3.0 License. 